\title{
The Potential of Serratia marcescens: An Indigenous Strain Isolated from Date Palm Compost as Biocontrol Agent of Rhizoctonia solani on Potato
}

\author{
Rabeb El Khaldi ${ }^{1,3 *}$, Majda Daami-Remadi ${ }^{2}$, Walid Hamada ${ }^{3}$, Lamia Somai ${ }^{3}$ and Mohamed Cherif ${ }^{4}$
}

${ }^{1}$ Centre de Recherche Régional en Agriculture Oasienne, 2260, Tozeur, Tunisia

${ }^{2}$ UR13AGR09-Production Horticole Intégrée au Centre Est Tunisien, Centre Régional des Recherches en Horticulture et Agriculture Biologique, Université de Sousse, 4042, Chott-Mariem, Sousse, Tunisia

${ }^{3}$ Institut National Agronomique de Tunisia, Tunisia

${ }^{4}$ Centre Technique des Agrumes, 8099, Beni khalled, Tunisia

\begin{abstract}
Rhizoctonia solani, associated with stem canker and black scurf diseases of potato, was one of the most destructive pathogens in Tunisia and elsewhere. A bacterial strain was isolated from date palm compost, identified as Serratia marcescens using amplification and sequencing of the 16SrRNA in combination with biochemical characterization. The antifungal properties against $R$. solani AG3 strain were assessed on potato. Mycelial growth inhibition of the pathogen was evaluated after 6 days of incubation at $28^{\circ} \mathrm{C}$ in the presence of the bacterium and its cell-free culture filtrates. The application of bacterial suspension adjusted to $10^{8} \mathrm{CFU} / \mathrm{ml}$ as pre-planting treatment of potato seeds tubers cv. Nicola reduced the incidence and severity of diseases under greenhouses conditions. In pot experiments, no stem canker was detected and the percentage of progeny tubers showing symptoms of black scurf was significantly reduced With $S$. marcescencs treatment $(36.47 \%)$ as compared to the controls. Results of this study suggest also that S. marcescencs was an effective biocontrol agent against black scurf and stem canker of potato since severity was reduced up to $49.31 \%$ and $83.16 \%$ respectively. Therefore, the bacterium could be considered as promising alternative to chemical products.
\end{abstract}

Keywords: R. solani; S. marcescens; Cell free culture filtrate; Disease incidence; Disease severity; Plant growth

\section{Introduction}

The widespread soil-borne pathogen Rhizoctonia solani is the causal agent of Rhizoctonia disease complex in potato (Solanum tuberosum L.) resulting in two different appearances of the disease, namely stem canker and black scurf which lead to tuber yield reductions and losses in tuber quality [1].

Stem canker consists of brown and black sunken stem lesions which involve the reduction of nutrient in the whole plant as a result losses of yield, whereas black scurf is revealed by the formation of brown or black sclerotia on tuber surfaces, which may affect their quality and marketability [2-4].

$R$. solani perpetuates in soil and tubers in the form of sclerotia. Seed-borne inoculum of $R$. solani can be a significant factor in the development of disease [5,6]

Control measures through cultural practices and chemical fungicides are used but they are not completely effective and Rhizoctonia disease remains a persistent problem. In addition chemical treatments are becoming increasingly difficult due to concerns about health and environmental hazards.

Biological control of Rhizoctonia diseases using microorganisms or their secretions has been demonstrated in some cases and offers an attractive alternative to overcome the disease and may provide effective and sustainable management [4,7-9].

Effectiveness of bacteria isolated from composts as potential biocontrol against plant diseases has been extensively described in many papers [10-13].

Several bacterial strains have been identified as biocontrol agents with antifungal activity against a large spectrum of plant diseases in natural environments and may be used to replace chemical control.

Serratia species, usually found in diverse natural environments, have been found to reduce disease severity of various foliar and soilborne diseases [14-18]. Among Serratia species, S. marcescens was reported as an important bacterium that has the ability to induce systemic resistance to various pathogens and to exhibit antifungal activity against several soil-borne fungi.

The objective of this research was to evaluate the potential of using a strain of $S$. marcescens isolated from date palm compost as biological control agent to reduce the impact of stem canker and black scurf caused by $R$. solani in potato. The efficacy of $S$. marcescens to control $R$. solani was tested using in vitro plate agar assay and under greenhouses conditions in artificially infested peat-sand growth media. The effect of the antagonist isolate on plant growth was also investigated.

\section{Materials and Methods}

\section{Source of the antagonistic bacterium}

The bacterium was isolated from date palm waste compost obtained by aerobic windrow composting. The composting crushed dry date palms wastes material was mixed with sheep manure at the ratio of $2: 3$ and $1: 3(\mathrm{v} / \mathrm{v})$, respectively and piled in a $3.90 \mathrm{~m}$ long by $2.70 \mathrm{~m}$ wide by $1 \mathrm{~m}$ high windrow on a concrete floor with an open air. The moisture content of the compost was maintained at approximately $60 \%$ by sprinkling with water. The compost from the pile was used as

*Corresponding authors: Rabeb El Khaldi, Centre Régional de Recherches en Agriculture Oasienne. Déguache, Tozeur 2260, Tunisia, Tel: +21676420085; Fax: +21676420085; E-mail: rabebk@yahoo.com

Received June 12, 2015; Accepted June 26, 2015; Published June 29, 2015

Citation: El Khaldi R, Remadi MD, Hamada W, Somai L, Cherif M (2015) The Potential of Serratia marcescens: An Indigenous Strain Isolated from Date Palm Compost as Biocontrol Agent of Rhizoctonia solani on Potato. J Plant Pathol Microbiol S3: 006. doi:10.4172/2157-7471.S3-006

Copyright: (C) 2015 El Khaldi R, et al. This is an open-access article distributed under the terms of the Creative Commons Attribution License, which permits unrestricted use, distribution, and reproduction in any medium, provided the original author and source are credited. 
the source of microorganisms. At the end of the process, the compost had the following major physico-chemical characteristics: $\mathrm{pH} 6.3,1 \%$ nitrogen, $91.8 \%$ organic matter, $78.3 \%$ carbon and $37.3 \mathrm{C} / \mathrm{N}$.

\section{Isolation and purification of the antagonistic bacterium}

The bacterium was isolated on Trypto-Casein Soja agar medium (TSA) from compost suspension obtained by adding 10 grams of compost sample to $90 \mathrm{ml}$ sterile distilled water. After being shaked at room temperature on a rotating shaker for $1 \mathrm{~h}$ at $120 \mathrm{rpm}$, the mixture was then filtered through four layers of sterile gauze. The suspension was serially diluted $\left(10^{-1}\right.$ to $\left.10^{-7}\right)$ and spread onto TSA plates then incubated at $28^{\circ} \mathrm{C}$ for $48 \mathrm{~h}$ and the subsequent purified bacterium was stored at $4^{\circ} \mathrm{C}$ on the same medium until future use.

\section{Valuation of the antifungal activity of the isolated bacterium against Rhizoctonia solani in vitro}

Plate antagonism assay: In vitro PDA plate pairing assay was used, as described by Bezert et al. [19], to determine the effect of $S$. marcences on $R$. solani mycelial growth. Two mycelial plugs of actively growing $R$. solani were placed $5 \mathrm{~cm}$ apart on PDA in a $90 \mathrm{~mm}$ Petri dish. A streak of the test bacterium was placed between the plugs $(2.5 \mathrm{~cm}$ from each plug). Control plates consisted of the mycelial plugs without bacterium. Three replicate plates were prepared and then incubated at $28{ }^{\circ} \mathrm{C}$. Inhibition of fungal growth was noted after 5-7 days. The experiment was repeated to confirm initial results.

\section{Effect of cell free culture filtrates of $S$. marcescens}

After 24 -h growth on a TSA medium at $28^{\circ} \mathrm{C}$, the bacterium was re-inoculated into a liquid medium (Trypto-Casein Soja broth medium:TSB) for $72 \mathrm{~h}$. Crude extracts were obtained by centrifuging broth culture at $8000 \mathrm{rpm}$ at $+4^{\circ} \mathrm{C}$ for $20 \mathrm{~min}$. The extracts were further filter-sterilized $(0.22 \mu \mathrm{m}$ filter $)$ prior to use. Antifungal potential of cellfree extracts of $S$. marscens was detected using the agar-well diffusion test and the pouring test.

The effectiveness of the bacterium crude culture filtrate by agar diffusion was tested by placing $100 \mu \mathrm{L}$ aliquots of the cell free extract into a $6 \mathrm{~mm}$ well cut in PDA plate equidistant from the $6 \mathrm{~mm}$ plug of R. solani $[20,21]$.

In the pouring method, filter-sterilized extracts were mixed in PDA (cooled at $45^{\circ} \mathrm{C}$ ) based on the ratio of 1:4. Once the agar has solidified, a $6 \mathrm{~mm}$ mycelial plug of $R$. solani was placed centrally on the agar [22].

Plates were incubated for 7 days at $28^{\circ} \mathrm{C}$. Control plates were prepared and incubated similarly, substituting the extracts with sterile distilled water. The diameter of $R$. solani inoculated on medium with extracts was calculated against the diameter of the pathogen on agar with sterile distilled water and the percentage of inhibition of the growth diameter was determined. Three plates were used per experiment and the whole experiment was repeated twice.

\section{Bacterial identification: 16S rDNA gene sequencing}

The genomic DNA of antagonist was extracted using the innuPREP DNA/RNA Mini Kit (Analytik Jena, Biometra) according to manufacturer instructions. The $16 \mathrm{~S}$ rDNA primers used are universal bacterial primers: $27 \mathrm{~F}$ and $1492 \mathrm{R}$. PCR reaction was performed in a total reaction volume of $25 \mu \mathrm{L}$ containing $5 \mu \mathrm{l}$ of buffer $(5 \mathrm{x}), 2.5 \mu \mathrm{l}$ of dNTP $(2 \mathrm{mM}), 1.5 \mu \mathrm{l}$ of $\mathrm{MgCl}_{2}(25 \mathrm{mM}), 0.25 \mu \mathrm{l}$ Taq polymerase ( 5 $\mathrm{U} / \mu \mathrm{l}), 2.5 \mu \mathrm{l}$ of each primer $(6 \mu \mathrm{M}), 5.75 \mu \mathrm{l}$ of ultra-pure water and $5 \mu \mathrm{l}$ of genomic DNA templates (10 ng). The amplification program, performed in an OpticonII (Biorad) Thermocycler, included an initial denaturation at $94^{\circ} \mathrm{C}$ for $5 \mathrm{~min}$, followed by 30 cycles of denaturation at $94^{\circ} \mathrm{C}$ for $1 \mathrm{~min}$, annealing at $50^{\circ} \mathrm{C}$ for $1 \mathrm{~min}$ and extension at $72^{\circ} \mathrm{C}$ for $1 \mathrm{~min}$. Amplification was terminated by a final extension step of 7 min at $72^{\circ} \mathrm{C}$. PCR products, checked on agarose gel, were subsequently purified and sequenced by private company (Biotools, Tunisia) using Forward and Reverse PCR primers of $16 \mathrm{~S}$ r-DNA. Finally, the BLAST program of the National Center for Biotechnology Information was used to analyze the obtained sequences (http://www. blast.ncbi.nlm. nih.gov/)

\section{Biocontrol activity of the antagonistic bacterium in greenhouse trials}

Inocula preparation and pot bioassays: The efficacy of the selected bacterium was evaluated for its control of Rhizoctonia stem canker and black scurf on potato. Pathogen inoculum was prepared by scraped off mycelium and sclerotia of $R$. solani from 10 day-old cultures and then, homogenized with sterile distilled water in a blender for $5 \mathrm{~min}$. The pathogen preparation was mixed with autoclaved peat-sand mixture (one Petri dish per $100 \mathrm{ml}$ distilled water per pot). Non-infested mixture served as a control [23].

Potato (Solanum tuberosum L.) seed tubers (cv. Nicola, Class A) were superficially disinfected with a solution of sodium hypochlorite (diluted at 2\%) for $20 \mathrm{~min}$ and then rinsed with sterile distilled water and air dried. Seed treatment was performed using a suspension of $S$. marcescens produced by culturing the bacterium in trypto-caseine soja broth (TSB) on a rotary shaker $\left(120 \mathrm{rpm}, 28^{\circ} \mathrm{C}\right)$. Tuber seeds were immersed for $30 \mathrm{~min}$ in the bacterial cell suspension obtained from a $48 \mathrm{~h}$ culture broth and adjusted to $10^{8} \mathrm{cfu} / \mathrm{ml}$ as determined by dilution plating and $560 \mathrm{~nm}$ optic density analysis. Seeds treated with water were used as controls. Seeds were planted in 5 liters plastic pot and grown in the greenhouse $\left(18-25^{\circ} \mathrm{C}, 16 \mathrm{~h}\right.$ light) for eight weeks and watered every 3 days.

\section{Effect of $S$. marcescens on plant yield and on suppression of stem canker and black scurf}

Plant yield and biocontrol potential were assessed on plants after harvest. Dry aerial parts and tuber fresh weights were determined. Stems and tubercles were washed with tap water, dried in air and examined for Rhizoctonia disease incidence and severity. Disease severity was assessed using the collar necrosis index (CNI) and the index of progeny tubers (IPT) infection by $R$. solani sclerotia according to the scales used by Daami-Remadi et al. [24] and the Official French scale disease on tubers [25].

Incidence of stem canker was calculated as the percentage of plants with a severity rating of 2 or more and the incidence of black scurf was calculated as the percentage of tubers with a severity rating of 1 or more according to the method of Brewer and Larkin [4].

\section{Statistical analysis}

The plant bioassay was designed as a randomized complete block with five replicates. Each replicate consisted of one pot containing one potato seed pieces. This study was conducted in two separate experiments. The agar assay was analyzed as a paired comparison between bacterium and the pathogen-only. Statistical analysis was performed with the STATISTICA software version 5 and comparisons of group means were accomplished with the Newman-Keuls test at $P$ $=0.05$ 


\section{Results}

\section{Antifungal activities of $S$. marcescens and its cell free culture filtrates on mycelium growth of $R$. solani}

In vitro antagonism assays (Figure 1) showed that the compost strain of $S$. marcescens is an antagonist to $R$. solani. The bacterium exhibited an antagonistic activity through antibiosis. After 6 days, growth of $R$. solani at $28^{\circ} \mathrm{C}$ was reduced to approximately $30 \%$ compared with that in the absence of bacterium.

The cell free culture filtrates collected from liquid culture show an inhibition in both test agar -well diffusion and pouring tests, relative to the R. solani control (Figure 2). Pouring test was found to be more efficient than agar-well diffusion with reductions of respectively $65.6 \%$ \pm 0.21 and $21.8 \% \pm 0.24$

\section{Identity of the antagonist strain}

Biochemical tests achieved using the API20E indicate that the bacterium strain belonged to the genus Serratia. After sequencing $16 \mathrm{~S}$ r-DNA PCR product with Forward and Reverse primers, NCBI BLAST results showed that the sequence has $\geq 99 \%$ DNA identity with $S$. marcescens $16 \mathrm{~S}$ rDNA gene. On the basis of BLAST result, it was found that the strain isolated from compost date palms was $S$. marcescens.

\section{Suppression of stem canker and black scurf after S. marcescens treatment}

In the $R$. solani-potato pathosystem, the experiment was ended after 8 weeks under greenhouse conditions. S. marcescens isolate was screened for suppression of stem canker and black scurf (Table 1). The bacterium applied as a seed treatment in the peat-sand infested with $R$. solani provided significant suppression $(P=0.05)$ relative to the pathogen check without bacterium. Black scurf incidence was reduced by $36.47 \%$ compared with $100 \%$ of progeny tubers with sclerotia in the absence of bacterium treatment. All treated plants have healthy stems.

\section{Effect of $S$. marcescens on stem canker and black scurf severity}

Disease severity assessment was determined by using 0-5 disease severity scale. Disease severity over the experimental bioassay was significantly low as compared to the infested controls. The results showed that the application of the strain $S$. marcescens reduced significantly the severity of symptoms of black scurf (Figure 3) and stem canker. Treatments with the bacterium strain led to reductions in the disease index of $49.31 \%$ and $83.16 \%$, respectively for black scurf and stem canker compared to the non-inoculated pathogen controls (Figures 4 and 5).

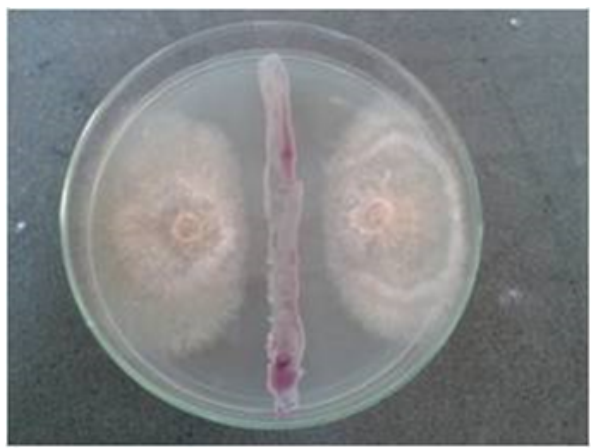

Figure 1: Radial growth inhibition of Rhizoctonia solani co-cultured with Serratia marcescens strain at $28^{\circ} \mathrm{C}$ for 6 days.
$R$. solani+sterile distilled water $R$, solani+cell free culture filtrate

A

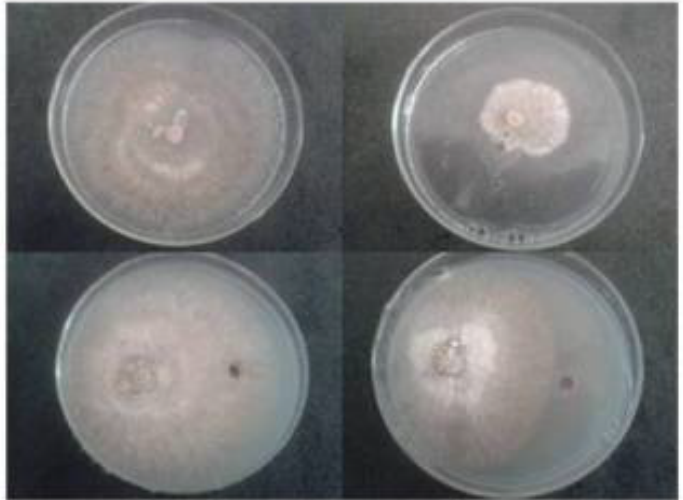

Figure 2: Radial growth inhibition of Rhizoctonia solani co-cultured with Serratia marcescens cell free culture filtrates at $28^{\circ} \mathrm{C}$ for 6 days in pouring test $(A)$ and agar-well diffusion test $(B)$.

\begin{tabular}{|c|c|c|c|c|}
\hline & \multicolumn{2}{|c|}{ Black scurf } & \multicolumn{2}{c|}{ Stem canker } \\
\hline Treatment & DI\% & $\begin{array}{c}\text { Reduction } \\
\text { in DI (\%) }\end{array}$ & DI\% & Reduction in DI (\%) \\
\hline Uninfested controls & $0 \mathrm{~b}$ & - & $0 \mathrm{c}$ & - \\
\hline Infested controls & $100 \mathrm{a}$ & - & $82.14 \mathrm{~d}$ & - \\
\hline S. marcscens & $63.53 \mathrm{a}$ & 36.47 & 0c & 100 \\
\hline
\end{tabular}

Table 1: Effect of $S$. marcescens treatment on Rhizoctonia stem canker and black scurf incidence (DI) noted on potato plants eight weeks post-planting in substrate artificially infested with $R$. solani. Means followed by the same letter are not significantly different from each other at $P=0.05$ based on Newman-keuls test.

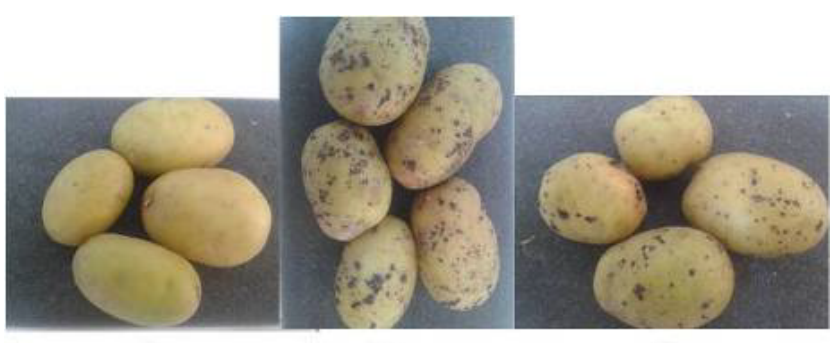

A

B

C

Figure 3: Severity of black scurf observed, eight weeks post-planting, on potato cv. 'Nicola' plants inoculated with Rhizoctonia solani and treated Serratia marcescens as compared to the controls. (A): Non inoculated with $R$. solani and non-treated; (B): Inoculated with R. solani and non treated; (C): Inoculated with $R$. solani and treated with Serratia marcescens.

\section{Growth-promoting effects}

The tested strain S. marcescens did not have a good growthpromoting effect on potato. None of the growth parameters, such as tuber dry weight and dry aerial part weight, was significantly $(P=0.05)$ increased as compared to non-inoculated controls (Table 2).

\section{Discussion}

Rhizoctonia disease, caused by $R$. solani, is one of the soil-borne diseases in potato plants. The fungus does not sporulate; thus, the sclerotia are the survival and dissemination units. Sclerotia in soil are very hard to be suppressed and the control using either fungicides or resistant cultivars was unsuccessful up to date.

In our experiment, $S$. marcescens, an isolated strain from compost 


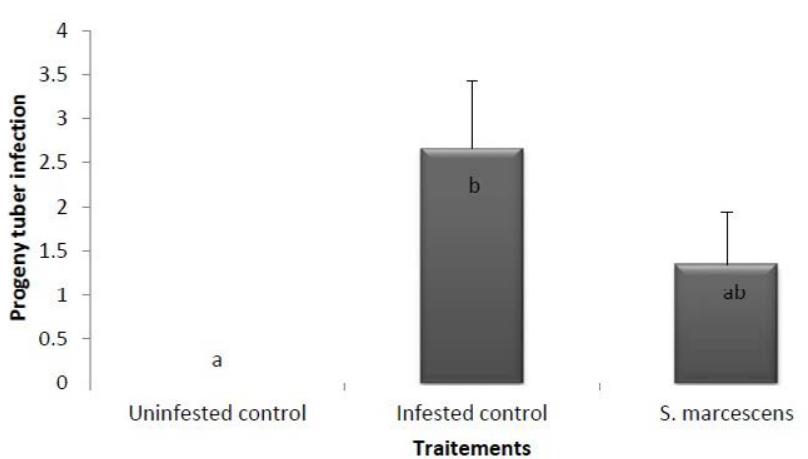

Figure 4: Progeny tuber infection, noted eight weeks post-planting, on potato plants cv. 'Nicola' treated with S. marcescens as compared with controls. Means followed by same letter are not significantly different from each other at $P=0.05$ based on Newman-keuls test.

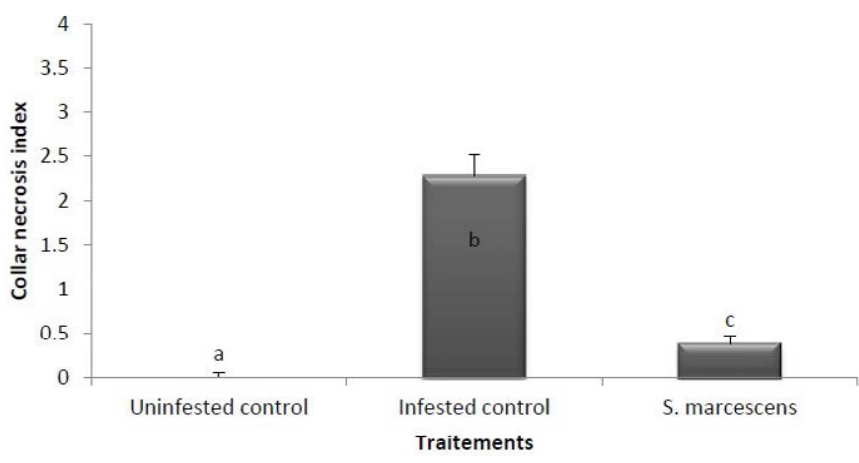

Figure 5: Collar necrosis index, noted eight weeks post-planting, on potato plants cv. 'Nicola' treated with S. marcescens as compared with controls. Means followed by same letter are not significantly different from each other at $P=0.05$ based on Newman-keuls test.

\begin{tabular}{|c|c|c|}
\hline Treatment & Tuber fresh weight $\mathbf{( g )}$ & Dry aerial part weight $\mathbf{( g )}$ \\
\hline Uninfested controls & $159.4 \pm 11.6$ & $9.8 \pm 1.5$ \\
\hline Infested controls & $126.1 \pm 8.8$ & $8.3 \pm 0.3$ \\
\hline S. marcscens & $142.1 \pm 7$ & $9.6 \pm 0.4$ \\
\hline
\end{tabular}

Table 2: Progeny tubers fresh weight and dry aerial part weight \pm SE, noted eight weeks post-planting, on potato plants cv. 'Nicola' treated with S. marcescens compared with controls.

date palm and sheep manure was isolated, identified, characterized and used to control rhizoctonia disease. Fungal growth and sclerotial germination of $R$. solani AG3 strain were inhibited in the presence of the bacterium and its cell free culture filtrates in vitro. These results suggested that $S$. marcescens could be used as an effective biocontrol agent against $R$. solani. Our results indicate that under greenhouse conditions, the bacterium significantly improved suppression of incidence and severity of the disease. The highest control efficiency was observed on stem canker than on black scurf. In accordance with our results, many studies have proved the successful use of $S$. marcescens as biocontrol agent. Villar de Queiroz and Soares de Melo [26] reported that the biological control of Phytophthora parasitica by a strain of $S$. marcescens R-35, isolated from citrus rhizosphere in greenhouse trials, suppressed more than $50 \%$ of the disease. In addition, Jaiganesh et al. [18] found that out of the six-bio protectants testes, S. marcescens was very effective against Pyricularia oryzae under in vitro conditions and when applied in rice field with a concentration of $2.5 \mathrm{~kg} / \mathrm{ha}$, the bacterium achieved the maximum disease control. In the rice sheath blight caused by $R$. solani AG1, Someya et al. [27] have used $S$. marcescens as effective and persistent biological control.

The occurrence of an inhibition zone by the bacterium isolate is believed to be the result of antibiosis through which the antagonist suppresses the disease. Many researches confirm our findings. Indeed, Kamensky et al. [28] suggested that the antifungal action of the Serratia may be based on antibiosis, as well as the production of siderophores and fungal cell-wall degrading enzymes-chitinases. This broad-spectrum activity is likely due, in part, to inhibitory metabolites produced by these organisms. Inhibitory metabolites produced by isolates of Serratia include mainly cell wall and cell-membrane degrading enzymes such us chitinases.

Someya et al. [14] tested the antifungal activities against $R$. solani sclerotia by $S$. marcescens strain culture filtrate. They demonstrate that suppression germination of $R$. solani sclerotia was attributed to chitinolytic enzymes and antifungal low-molecular-weight compounds present in filtrates of $S$. marcescens. The same result was found by Akutsu et al. [15]. Those authors showed the potential of S. marcescens, a strain isolated from tomato phylloplane, to inhibit several species of the genus Botrytis and suggest, via culture filtrate of the bacterium, that the inhibitory effect of $S$. marcescens was correlated with its chitinolytic activity.

Many of the previous studies that characterized the role of bacterial chitinases in biocontrol focused on S. marcescens in which the ability to produce this cell wall degrading enzyme of the fungus is considered crucial for antifungal activity [29-33]

Another approach was suggested by Dipanwita et al. [34] which involve the production of antibiotics such as the red pigment prodigiosin and pyrrolnitrin, besides chitinases and siderophores as main protagonist of the biological control by Serratia species.

Despite the potential role in reducing Rhizoctonia disease, the obtained S. marcescens strain has no significant effect on plant growth. This result is in contrast with those obtained by Villar de Queiroz and Soares de Melo [26] for which the strain S. marcescens R-35, can promote the growth of citrus.

According to our research work, the compost strain S. marcescens could be used as a potential biological control agent against $R$. solani AG3. Further evaluation of serratia chitinase for control of $R$. solani AG3 will be needed to valorize the chitinolytic ability in development of successful biocontrol strategy.

\section{References}

1. Baker KF (1970) Types of Rhizoctonia diseases and their occurrence. In: Parmeter, Jr, JR (ed) Rhizoctonia solani. Biology and Pathology. University of California Press, Berkeley, CA, pp. 125-148.

2. Tsror (Lahkim) L, Barak R, Sneh B (2001) Biological control of black scurf on potato under organic management. Crop Prot 20: 145-150.

3. Schwartz HF, Gent DH (2005) Rhizoctonia Stem Canker. Potato XXII.

4. Brewer MT, Larkin RP (2005) Efficacy of several potential biocontrol organisms against Rhizoctonia solani on potato. Crop Prot 24: 939-950.

5. Banville GJ (1989) Yield losses and damage to potato plants caused by Rhizoctonia solani Kuhn. American Potato Journal 66: 821-834.

6. Carling DE, Leiner RH, Westphale PC (1989) Symptoms, signs and yield reduction associated with Rhizoctonia disease of potato induced by tuber borne inoculum of Rhizoctonia solani AG3. American Potato Journal 66: 693-701.

7. Moussa TAA (2002) Studies on Biological Control of Sugarbeet Pathogen Rhizoctonia solani $K \tilde{A}^{1} / 4 \mathrm{hn}$. OnLine Journal of Biological Sciences 2: 800-804.

8. Grosch R, Scherwinski K, Lottmann J, Berg G (2006) Fungal antagonists of the 
Citation: El Khaldi R, Remadi MD, Hamada W, Somai L, Cherif M (2015) The Potential of Serratia marcescens: An Indigenous Strain Isolated from Date Palm Compost as Biocontrol Agent of Rhizoctonia solani on Potato. J Plant Pathol Microbiol S3: 006. doi:10.4172/2157-7471.S3-006

plant pathogen Rhizoctonia solani: selection, control efficacy and influence on the indigenous microbial community. Mycological Research IIO: 1464-1474.

9. Lewis JA, Lumsden RD (2001) Biocontrol of damping-off of greenhouse-grown crops caused by Rhizoctonia solani with a formulation of Trichoderma spp. Crop Protection 20: 49-56.

10. Kerkeni A, Dammi-Remadi M, Tarchoun N, Ben Khedher M (2008) Effect of bacterial isolates obtained from animal manure compost extracts on the development of Fusarium oxysporum f. sp. radicis-lycopersici. Asian Journal of Plant Pathology 2: 15-23.

11. Suarez-Estrella F, Vargas-Garcia MC, Lopez MJ, Capel C, Moreno J (2006) Antagonistic activity of bacteria and fungi from horticultural compost against Fusarium oxysporum f. sp. melonis. Crop Protection 26: 46-53.

12. Suarez-Estrella F, Arcos-Nievas MA, Lopez MJ, Vargas-Garcia MC, Moreno J (2013) Biological control of plant pathogens by microorganisms isolated from agro-industrial composts. Biological Control 67: 509-515

13. Ying L, Daolin D, Chuncan S, Qingsong Z, Zhiguo L, et al. (2014) Potentia biocontrol Bacillus sp. strains isolated by an improved method from vinegar waste compost exhibit antibiosis against fungal pathogens and promote growth of cucumbers. Biological Control 71: 7-15.

14. Someya N, Kataoka N, Komagata T, Hibi T, Akutsu K (2000) Biological contro of cyclamen soil borne diseases by Serratia marcescens strain B2. Plan Disease, 84: 334-340.

15. Akutsu K, Hirata A, Yamamoto M, Hirayae K, Okuyama S, et al. (1993) Growth inhibition of Botrytis spp. by Serratia marcescens B2 isolated from tomato phylloplane. Jpn J Phytopathol 59: 18-25.

16. Iyozumi H, Hirayae K, Komagata T, Tsuchiya K, Hibi T, et al. (1996) Bio control of cyclamen grey mould by Serratia marcescens B2. Ann Rev Phytopathol Soc Japan 62: 559-565.

17. El-Tarabily KA, Soliman MH, Nassar AH, Al-Hassani HA, Sivasithamparam AH et al. (2000) Biological control of Sclerotinia minor using chitinolytic bacterium and actinomycetes. Phytopathology 49: 573-590.

18. Jaiganesh V, Eswaran A, Balabaskar P, Kannan C (2007) Antagonistic activity of Serratia marcescens against Pyricularia Oryze. Not Bot Hort Agrobot Cluj 35: $48-54$

19. Bezert G, Chappe P, Mourey A, Loubinoux B (1996) Action de Bacillus et Actinomyctes sur les champignons du bleuissement du bois. Bulletin des Acadamie et Socia Lorraines des Sciences 35 No 3.

20. Landa BB, Hervas A, Bettiol W, Jimenez-Daz RM (1997)1 Antagonistic activity of bacteria from the chickpea rhizosphere against Fusarium oxysporum f.sp. ciceris. Phytoparasitica 25: 305-318.
21. Jackson AJ, Walters DR, Marshall G (1994) Evaluation of Penicillium chrysogenum and its antifungal extracts as potential biological control agents against Botrytis fabae on faba beans. Mycol Res 98: 1117-1126.

22. Zacky FA, Ting AY (2013) Investigating the bioactivity of cells and cell-free extracts of Streptomyces griseus towards Fusarium oxysporum f. sp. cubense race 4. Biological control 66: 204-208

23. Daami-Remadi M, Zammouri S, El Mahjoub M (2008a) Relative susceptibility of nine Potato (Solanum tuberosum L.) cultivars to artificial and natural infection by Rhizoctonia solani as measured by stem canker severity, black scurf and plant growth.African J Plant Sci Biotech 2: 57-66.

24. Daami-Remadi M, Zammouri S, El Mahjoub M (2008b) Effect of the level of seed tuber infection by Rhizoctonia solani at planting on potato growth and disease severity. Afr J Plant Sci Biotechnol 2: 34-38.

25. Anonyme (2009) Official French scale of the tubers diseases.

26. Villar de Queiroz BP, Soares de Melo I (2006) Antagonism of Serratia marcescens towards Phytophthora parasitica and its effects in promoting the growth of citrus Braz. J Microbiol 37: 448-450.

27. Someya N, Nakajima M, Watanabe K, Hibi T, Akutsu K (2005) Potential of Serratia marcescens strain B2 for biological control of rice sheath blight Biocontrol Science and Technology 15: 105-109.

28. Kamensky M, Ovadis M, Chet I, Chernin L (2003) Soil-borne strain IC14 of Serratia plymuthica with multiple mechanisms of antifungal activity provides biocontrol of Botrytis cinerea and Sclerotinia sclerotiorum diseases. Soil Biol Biochem 35: 323-331.

29. Fuchs RL, McPherson SA, Drahos DJ (1986) Cloning of a Serratia marcescens Gene Encoding Chitinase. Appl Environ Microbiol 51: 504-509.

30. Jones JD, Grady KL, Suslow TV, Bedbrook JR (1986) Isolation and characterization of genes encoding two chitinase enzymes from Serratia marcescens. EMBO J 5: 467-473.

31. Ordentlich A, Elad Y, Chet I (1988) The role of chitinase of Serratia marcescens in the biocontrol of Sclerotium rolfsii. Phytopathology 78: 84-88.

32. Shapira R, Ordentlich A Chet I, Oppenheim AB (1989) Control of plant diseases by chitinase expressed from cloned DNA in Escherichia coli. Phytopathology 79: $1246-1249$

33. Kishore GK, Pande S, Podile AR (2005) Biological Control of Late Leaf Spot of Peanut (Arachis hypogaea) with Chitinolytic Bacteria. Phytopathology 95: 1157-1165.

34. Dipanwita S, Gargi DP, Aniruddha S (2012) Biological Control of Plant Diseases by Serratia Species: A Review or a Case Study. Frontiers on Recent Developments in Plant Science 17: 99-115. 